\title{
The evaluation of the levels of histology self- efficacy beliefs of students of dentistry faculty
}

\author{
Aysegul Aytekin ${ }^{1 \mathrm{a}}$, Liridona Adili Osmani ${ }^{1}$, Mehmet Hamdi Aytekin ${ }^{2}$, Yusufhan Yazir $^{1}$, and \\ Melda Yardimoglu Yilmaz ${ }^{1}$
}

${ }^{1}$ Kocaeli University Faculty of Medicine, the Department of Histology, Kocaeli, Turkey

${ }^{2}$ Kocaeli Training and Research Hospital, Kocaeli, Turkey

\begin{abstract}
Histology is one of the foundational courses of the faculties which give health education. In order to be successful in the field of dentistry, one should master the basic histology knowledge. The histology courses in Kocaeli University Faculty of Dentistry are held as General Histology and Oral Histology beginning from the second grade. The purpose of our study is to evaluate the effect of the histology courses taken, on the Histology Self- Efficacy Beliefs (HSEB) in the students of the department of dentistry. 16 male $(21,3 \%)$ and 59 female $(78,7 \%)$ students (75 in total) from the $2^{\text {nd }}$ grade of the faculty of dentistry have contributed to our study. Some personal information like gender, geographical regions where they come from and places where they dwell and the self- efficacy belief scale have been implemented on the students who participated in the study. In the direction of the obtained information and from the HSEB point of view, there is one student from the Southeastern Anatolia region who with 40 points ranks at the last row. In conclusion, we think that since the level of development of the Southeastern Anatolia region is low, this may have a negative effect on the students who live there and for this reason, we think this is why the HSEB levels of the students who come from the Southeastern Anatolia region are low.
\end{abstract}

Keywords: Histology, dentistry, self-efficacy, education

\section{Introduction}

Histology is one of the foundational courses of the faculties which give health education. In order to be successful in the field of dentistry, one should master the histology basic

\footnotetext{
${ }^{a}$ Corresponding author: dr.a.albayrak@gmail.com
} 
knowledge. The histology courses in Kocaeli University Faculty of Dentistry are held as General Histology and Oral Histology beginning from the second grade. The purpose of our study is to evaluate the effect of the histology courses taken, on the histology education self-sufficiency beliefs (HESB) in the students of the department of dentistry.

In literature, self-sufficiency is defined as the ability of a person which he/she shows to overcome the incidents and the situations which he/she meets [1]. When a human being, either during his/her life or education, meets a problem, how well he/she implements the necessary actions which are necessary to solve the problem shows the self-sufficiency level of that individual about that subject. That is to say, the self-sufficiency level means the ability of the individual to realize and succeed in a work [2,3]. Self-sufficiency which is a concept which has been developed in the field of socio-psychology can be implemented in many different areas according to $[2,3,4]$.

In spite of the studies on education in departments which give health education show increase recently, we encountered the studies related to self-sufficiency only which Lök S. [6] and Taşdemir R. [3] had performed. In the literature search, it has been seen that the self-sufficiency belief scale is implementable in the field of education.

\section{Method}

75 students who receive education in the $2^{\text {nd }}$ grade of dentistry have participated in our study. The personal information survey (age, gender, geographical regions which they come from, the pace of residence) and the self-sufficiency belief scale for the histology education were implemented to the students who participated in our study.

The histology self-sufficiency belief scale (HESB) which is constituted of 15 articles was constituted by adapting the scale of Akkoyunlu et al. [4] and Çolak [2] to histology. The answers were in the form of 5-point Likert scale and the participation degrees of the students to each instruction were categorized as 1 "I never agree", 2 "I disagree", 3 "I am hesitant", 4 "I agree" and 5 "I completely agree" [5]. The statistical analysis of the data obtained was made with SPSS for Windows 18.0 packaged software.

\section{Results}

16 male $(21,3 \%)$ and 59 female $(78,7 \%)$ students $\left(75\right.$ in total) from the $2^{\text {nd }}$ grade of the faculty of dentistry have contributed to our study (average age: 20,16 $\pm 0,839$ ) (Table 1), Some personal information like gender, geographical regions where they come from and places where they dwell and the self-sufficiency belief scale have been implemented on the students who participated in the study.

Table 1. The distributions of the dentistry students according to gender.

\begin{tabular}{lll}
\hline Gender & Quantity & Percent \\
\hline Male & 16 & $21,3 \%$ \\
Female & 59 & $78,7 \%$ \\
Total & 75 & $100 \%$ \\
\hline
\end{tabular}

In the result of the evaluation, the relation between the personal information of the students and their HESB levels was evaluated. When the HESB levels according to gender were examined, the average of the HESB level of the boys is 44,13 $\pm 3,90$ and of the girls is $44,73 \pm 3,51$. A statistically meaningful difference between the genders and the HESB levels of the students according to the geographical regions they come from could not be found ( $p>0,05)$ (Table 2,3). 
Table 2. The average HESB distributions of the dentistry students according to gender.

\begin{tabular}{lccc}
\hline Gender & HESB average & Standard deviation & P value \\
\hline Male & 44,13 & 3,897 & 0,745 \\
Female & 44,73 & 3,513 & \\
Total & 44,60 & 3,579 & \\
\hline
\end{tabular}

The majority of the contribution is from the Marmara region with 45 persons $(60 \%)$. And those who come from the Black Sea and Aegean regions are ranked as the second with 9 persons (12\%). The Mediterranean region with 5 persons $(6,7 \%)$, the Central Anatolia region with 3 persons (4\%), the East Anatolia region with 2 persons $(2,7 \%)$ and the Southeast Anatolia region with 1 person $(1,3 \%)$ respectively followed these. When the HESB levels are compared according to geographical regions, the students who have the highest HESB levels are those who come from the Mediterranean region with 46,4 $\pm 1,67$. And the HESB level 45,3 $\pm 1,53$ ranked as the second belongs to those who come from the Central Anatolia region. In the direction of the obtained information and from the HESB point of view, there is one student from the Southeastern Anatolia region who with 40 points ranks at the last row.

Table 3. The average HESB distributions of the dentistry students according to geographical regions they come from.

\begin{tabular}{lccc}
\hline Geographical regions & HESB average & Standard deviation & P value \\
\hline Mediterranean Region & 46,40 & 1,673 & \\
East Anatolia Region & 44,50 & 3,535 & \\
Aegean Region & 44,89 & 5,207 & \\
Southeastern Anatolia Region & 40,00 & - & 0,625 \\
Central Anatolia Region & 45,33 & 1,528 & \\
Black Sea Region & 45,44 & 4,851 & \\
Marmara Region & 44,22 & 3,240 & \\
Total & 44,60 & 3,579 & \\
\hline
\end{tabular}

When evaluated according to places of residence, while the average of the HESB levels of the students who stay in the dormitory is $45,4 \pm 3,5$, the average of the HESB levels of the students who live in homes is $43,9 \pm 3,54$. A meaningful difference between the average of the HESB levels and the places of residence could not be found ( $p>0,05)$ (Table 4).

Table 4. The distributions of the average of HESB of the dentistry students according to places of residence.

\begin{tabular}{lccc}
\hline Places of residence & HESB average & Standard deviation & P value \\
\hline Home & 43,90 & 3,543 & 0,084 \\
Dormitory & 45,40 & 3,50 & \\
Total & 44,60 & 3,579 & \\
\hline
\end{tabular}

\section{Discussion}

When the genders, the ages and the geographical regions the students participated to the data survey used in our study were examined, it was found that those parameters do not have any effect on the HESB levels. Even though the HESB levels of the girls are higher according to the boys, any statistically meaningful difference could not be found $(p>0,05)$. 
And when the HESB values between the geographical regions are looked upon, the highest HESB level was found to be of the students who come from the Mediterranean region and again, no meaningful difference could be determined $(p>0,05)$.

And another parameter in the survey is determining and comparing the HESB levels according to the places of residence. In the result of the evaluation, when the HESB values of the students who live in homes or in the dormitory as places of residence, even though the average of HESB comes out to be high, no statistically meaningful difference could be found $(\mathrm{p}>0,05)$.

It can be said that the self-sufficiency perception of the dentistry students related to the histology course and their academic successes do not show difference according to the gender, the geographical region they come from and the places of residence, in other words, they do not change. According to these results, we think that the histology course selfsufficiency perceptions of the students may be independent from the conditions we questioned but these parameters should be searched in a more detailed way within themselves.

\section{References}

1. Bandura, A. Selfefficacy: Toward a unifying theory of behaviour change. Psychol. Rev. 84, 191-215 (1977).

2. Çolak, S. The Relationship Among Computer SelfEfficacy Scores, Demographic Charecteristics And Grades in Computer Courses Of Students at The School of Physical Education And Sports. Educational Research And Reviews. 8(8), 374-377 (2013).

3. Taşdemir, R. ve ark. The Comparıson of Self-Effıcacy Belıefs of Anatomy Between The First And The Second Class Students in Medical School. TOJET Special issue 2 for INTE 2015, 570-574 (2015).

4. Akkoyunlu, B., Orhan F. Bilgisayar ve Öğretim Teknolojileri Eğitimi (BÖTE) Bölümü Öğrencilerinin Bilgisayar Kullanma Öz Yeterlik İnancı ile Demografik Özellikleri Arasındaki İlişki. Turk. Online J. Educ. Technol. 2 (3), 8693 (2003).

5. Bozdoğan, A.E., Öztürk, Ç. Coğrafya İle İlişkili Fen Konularının Öğretimine Yönelik ÖzYeterlilik İnanç Ölçeğinin Geliştirilmesi. Necatibey Eğit. Fak. Elektronik Fen ve Mat. Eğit. Dergisi. 2(2), 66-81 (2008)

6. Lök, S., Taşğın, Ö., Lök, N., Yıldız, M. Karamanoğlu Mehmet Bey Üniversitesi Farklı Bölüm Öğrencilerinin Anatomi Dersine Olan Öz-Yeterlilik Durumlarının Karşılaştırılması. Selçuk Üni. Sosyal Bil. Ens. Dergisi. 21, 339-345 (2009). 